\title{
UDC 528.94:94(477=112.2)
}

\section{DOI: 10.24919/2312-2595.5/47.217779}

\section{Алла КРИЛОВА}

кандидат історичних наук, дочент кафедри історії та археології, Мелітопольський державний університет імені Богдана Хмельнииького, вул. Гетьманська, 20, м. Мелітополь, Україна, індекс 72312 (allakr2014@gmail.com)

ORCID: https://orcid.org/0000-0002-9507-1818

ResearcherID: http://www.researcherid.com/rid/V-3496-2017

Scopus ID: https://www.scopus.com/authid/detail.uri?authorId=57211294259

Бібліографічний опис статті: Krylova, А. (2020). Historical maps in GIS: scientific and methodological aspect (Molochna German settlement maps as example). Проблеми гуманітарних наук: збірник наукових пращь Дрогобиџького державного педагогічного університету імені Івана Франка. Серія Історія, 5/47, 466-485. doi: https://doi.org/10.24919/23122595.5/47.217779.

\section{ІСТОРИЧНІ КАРТИ В ГІС: НАУКОВО-МЕТОДИЧНИЙ АСПЕКТ (КАРТИ НІМЕЦЬКИХ ПОСЕЛЕНЬ МОЛОЧНОЇ ЯК ПРИКЛАД)}

Анотація. В украӥнських школах дуже мало уваги приділяється методологічним компонентам геоінформатики та методам навчання з використанням історичних карт у ГІС (геоінформаиійні системи). Метою дослідження є показати, як ГІС можна використовувати для викладання місиевої історії. Методологія дослідження базується на приниипах історизму, системності, науковості та об'єктивності, використанні загальнонаукових та спеиіально-історичних методів. Наукова новизна статті полягає у створенні й використанні інформачійних карт у ГІС, які розкривають історію німиів та менонітів Запорізької області як основного картографічного матеріалу для навчальних курсів $з$ місиевої історії. Такі карти показують соиіо-економічний розвиток різних етнічних груп та конфесій на Півдні України. Зокрема, менонітів та етнічних німиів, які зробили величезний внесок

(C) Alla Krylova, 2020 
у культурний і економічний розвиток регіону та залишили значний шар культурної спадщини. Висновок. Карти, представлені в иій статті, базуються на великій базі даних історичних джерел $i$ вже частково стали основою таких курсів, як "Історія Запорізької області», «Історичне краєзнавство», які викладаються у Мелітопольському державному педагогічному університеті. За допомогою ГІС-карт на перший план виходять різні первинні історичні джерела (статистичні, картографічні та ін.), що дадуть змогу вивчати місиеві територіальні одиниці. Стаття демонструє ГІС-карти 27 німецьких поселень Молочної (Прииибська волость) за певний період часу.

Ключові слова: Запорізька область; ГІС; Молочанські німецькі поселення; викладання; краєзнавство.

\section{Alla KRYLOVA}

PhD (History), Associate Professor, Department of History and Archeology, Bogdan Khmelnitsky Melitopol State Pedagogical University, 20 Getmanska Str., Melitopol, Ukraine, postal code 72312 (allakr2014@gmail.com)

ORCID: https://orcid.org/0000-0002-9507-1818

ResearcherID: http://www.researcherid.com/rid/V-3496-2017

Scopus ID: https://www.scopus.com/authid/detail.uri?authorId=57211294259

To cite this article: Krylova, A. (2020). Historical maps in GIS: scientific and methodological aspect (Molochna German settlement maps as example). Problemy humanitarnykh nauk: zbirnyk naukovykh prats Drohobytskoho derzhavnoho pedahohichnoho universytetu imeni Ivana Franka. Seriia IstoriiaProblems of Humanities. History Series: a collection of scientific articles of the Drohobych Ivan Franko State Pedagogical University, 5/47, 466-485. doi: https://doi.org/10.24919/2312-2595.5/47.217779.

\section{HISTORICAL MAPS IN GIS: SCIENTIFIC AND METHODOLOGICAL ASPECT (MOLOCHNA GERMAN SETTLEMENT MAPS AS EXAMPLE)}

Summary. In Ukrainian schools and high schools very little attention is paid to the methodological components of Geoinformatics and teaching methods using historical maps in GIS (geographic information systems). The purpose of the research is to show how GIS can be used in teaching local history. The research methodology is based on 
the principles of historicism, system-formation, scientific character, verification, the author's objectivity, moderated narrative constructivism, and the use of general scientific and specially-historical methods.

The scientific novelty of the article consists in the creation and use of information maps in GIS with regard to the history of Germans and Mennonites of the Zaporizhzhia oblast, as a basic cartographic material for training courses in local history. Such maps show the territory of Southern Ukraine in relation to various ethnic groups and faiths. In particular, Mennonites and ethnic Germans, who made a huge contribution to the cultural and economic development of the region and left a significant layer of cultural heritage.

The maps findings presented in this article are parts of a large database of historical sources, and have already partially become the basis of such courses of local history as "History of the Zaporizhzhia oblast", "Historical Local History" at Melitopol State Pedagogical University. With the help of GIS maps, various primary historical sources (statistical, cartographic, etc.) come to the forefront and allow the study of local territorial units. The article will demonstrate the GIS maps of 27 German settlements of Molochna German settlements (Prishibskaya volost) for a certain time period.

Conclusions. The use of historical GIS technologies contributes to the formation of such students' skills as read the information on the historical maps; search for objects or information by given parameters, for example, by name; carry out calculations on digital maps; to form the spatial thinking of students, demonstrating the historical objects in three dimensions; create digital maps by own, especially based on the results of student observations.

Key words: Zaporizhzhia oblast; GIS; Molochna German settlements; teaching; local history.

Problem statement. Schools and universities within Ukraine are constantly developing the technique and skills of using visual teaching computer methods. Importantly, regarding this is the use of GIS in various fields of knowledge. Academic disciplines such as "Historical Informatics" and "Geoinformation Systems" are included in the curricula of Ukrainian Universities. But a review of the programs of these courses has suggested that the main emphasis is on the general use of digital technologies in research or the teaching process. At the same time, very little attention is paid to the methodological component of geoinformatics and teaching methods which use historical 
maps in GIS. To improve the situation in Ukrainian Universities substantially, it is important to address the leading world experience in teaching historical courses using historical maps in GIS. In historical courses at schools and universities, it would be beneficial for teachers to increase their use to develop key academic competencies. Historians and history teachers are beginning to understand key aspects of GIS, such as the ability to integrate, analyze, and visualize large volumes of spatial and temporal data from different disciplines and sources. They are also beginning to understand the ability of technology to move at different scales, both spatially and temporally, geographically and historically. This ability to combine space and time in one integrated system has profound implications for research and education in the field of history and geography (Richardson, 2020).

Thus, the main goal of the project was to create the information maps in GIS of History of Germans and Mennonites in the Zaporizhzhia oblast as a cartographic material for local course "History of the Zaporizhzhia oblast".

Local GIS applications allow students to complete an in-depth study of local problems and conditions. The use of GIS technology involves spatial understanding, which, in turn, involves spatial thinking. Spatial thinking is considered fundamental and this knowledge is applicable throughout life (Lambrinos \& Asiklari, 2014).

The analysis of sources and recent researches. The use of international and Ukrainian experience in the creation of such projects allows the implementation of historical GIS projects in teaching local history. One of the most successful Ukrainian projects is the GISAtlas of the Holodomor of 1932-1933, created by the staff of the Institute of History of Ukraine (Boriak \& Sossa, 2012).

Belarusian researchers are successfully studying the use of geographic information technologies in education. Using GIS, they help the teacher and student to control the flow of information focusing on the most interesting or complex points of the material being studied. Interactive tools provide the ability to simulate geographical phenomena and processes, clearly demonstrating them in dynamics. Thus, they facilitate understanding of the essence of these phenomena and processes (Vinokurova, Badin, \& Badina, 2014).

One of the most famous archaeographic projects for visualizing historical sources, which can be useful in teaching history, was the 
KLEO project by professor Manfred Taller (Max Planck Institute). Thus, a source-oriented approach to any written source was implemented. Source-oriented data processing is a computer simulation of the entire amount of source information with the most accurate preservation of the features of the historical source (Riabko \& Kukharchuk, 2014).

Altaweel Mark (University College London) provides examples of how GIS has changed the field of history so that our understanding of historical events improves. He claims that teaching history now is made easier by visualizing to classrooms and students places mentioned and GIS analysis could be used to provide students with historical awareness. One area where GIS has been more recently used in understanding the past has been reconstructing sites or places so that one can visualize in $3 \mathrm{D}$ and understand how individuals experience cityscapes or landscapes in the past as they walked through them (Altaweel, 2020; Pinyagin, 2010).

Andrew J. Milson, a professor of history and geography at the University of Texas in Arlington, provides an overview and analysis of the theory, research, and practice associated with geospatial technology in social sciences. He explores the history of geospatial technology in education, the impact of standards movement and the growth of the international community of geospatial education. He provides examples and discussions on the use of geospatial technology to teach and study history, geography, citizenship, economics and environmental science (Milson \& Alibrandi, 2008).

Dr. Thomas C. Hammond (Lehigh University) claims that the community of geospatial technology educators has long been interested in engaging students in local research. Geospatial tools provide a way to explore and illustrate local conditions, including links to the main narrative presented in the history curriculum. For example, the question of what life was like then can be solved in several ways (Hammond, 2007).

When studying the history of human settlements, researchers draw on additional sources, including address books, reference books, election results, and other localized information. These sources formed the basis for the creation of GIS for two American cities - Newport and Alexandria. Spatial analysis leads researchers to rather unexpected conclusions. So, it is clear that the close proximity of water bodies and railways did not affect population density. Religious aspects of 
urban history are considered by American historians E. Diamond and D. Bodenhamer (Diamond \& Bodenhamer, 2001). The authors try to find the relationship between religious affiliation and race based on Indianapolis material. This study is an example of the fact that without a GIS, it is difficult for a historian to associate quality data with a geographic reference, and then visualize the results (Rygalova, 2014).

The project is in close connection with our historical studies on the territory of southern Ukraine, relating to various ethnic groups and faiths. In particular, Mennonites and ethnic Germans, who made a huge contribution to the cultural and economic development of the region and left a significant layer of cultural heritage. We have a large database of historical sources at our disposal (more than 100 thousand pages of archival copies), which have already partially become the basis of geoinformation maps of the Mennonite and German colonies.

GIS is considered one of the possibilities of using technologies in the process of studying the history of Germans in Southern Ukraine. The use of GIS is not only historical, but also universal, affecting various aspects of social development, although the historical component remains decisive. This treatment has great potential. The use of GIS in this direction makes it possible to visualize not only cartographic and statistical data, but also other types of sources. A large number of studies on the history of Russian Germans in various regions, including Molochna, require a more comprehensive approach and digitalization of data. This will help re-examine the already studied stages of their integration into the surrounding society.

The information obtained is presented in the form of a QGIS database (desktop 3.8.1). Thus, the use of GIS in this study allows you to analyze 27 German settlements of Prishibskaya volost for a certain time period and consider the demographic, economic and other aspects of its development.

The main historical sources (19th - early 20th centuries) that are used to create maps were Reference books on industry and agriculture (materials of the Ministry of Trade and Industry of Russia) (Adresnaya kniga zavodov, 1912). They were used to localize the main industrial and agricultural enterprises in the territory of Prishibskaya volost, as well as to analyze the activities of these enterprises.

In the process of research, we used reviews of the state of the settlements (documents of the Trusteeship Committee on Foreign Settlers 
of the Southern Territory of Russia (State Archives of Odessa Region), "Office of the Tauricheskiy Governor" and "Tauria Provincial Government" (State Archive of the Autonomous Republic of Crimea)) (Naselennye mesta, 1905), Reports of the governor and their annexes (Russian State Historical Archive) (Prilozhenie, 1890).

These sources were used to analyze the statistics of the population of the settlements, its changes in specific periods. It also provides data on the number of livestock in the settlements. Zemstvo (land administration) materials (resolutions of provincial and district Zemstvo, statistics) (Andrievskiy, 1915) provide extensive information about settlements, but primarily about statistics and the mobilization of landownership. Data from state censuses (revisions of the population, the All-Russian population census, etc.) (Information about the inhabited places. Melitopol uyezd, 1896) provide information on changes in the size of the national and religious composition of the population, the amount of land and social objects in the colonies.

Cartographic materials (3 verst map of Russia, county maps, plans of rural societies and estates) (Lebedev, 1889) allow you to localize the object in space and time. They provide the opportunity to create and analyze a historical map in GIS.

Information of modern reference books and publications (Dizendorf, 2006) provides an opportunity to clarify data on various aspects of the development of the settlements.

Based on the curriculum of the specialty "Secondary Education (History)", the local history course "History of the Zaporizhzhia oblast" was chosen. One of the topics of this course is the history of the Germans in the Zaporizhzhia oblast including the features of their resettlement and culture.

The study of this topic is focused on the creation and analysis of the historical and cultural development of the Germans in the Zaporizhzhia oblast. The main points are being studied: name (options, with renaming dates), settlement status; The time of existence (the occurrence or time of the first mention and liquidation); administrative subordination (in dynamics); the number of yards; population (abundance, composition); industry; agriculture and forestry; social development (churches, schools, trade); significant events; famous residents.

The main activity of the Germans in the area of the Molochna River took place from the beginning of the 19th century to the 20 s of 
the 20th century. There are some key dates used in the map creation process. 1812 was chosen as the data of initial period of German settlement process in Zaporizhzhia oblast; 1843 - completion of the formation of the resettlement network; 1864 - on the eve of the decree of 1871 , which allowed the colonists to sell public land; 1884 - shows the consequence of the decree of 1871 , when there is a reduction in the number of yards in many colonies; 1896 - the first All-Russian population census; 1913 - the eve of the First World War and the Civil War; 1925 - after the First World War and the Civil War.

The purpose of the publication. Thus, the cultural and landscape studies carried out using GIS are didactically located at the junction of key topics: "spatial orientation" and "time orientation".

Students should be able to formulate their own queries regarding local history, to form their own perception of the history of the region.

On the basis of GIS maps, students compare the current state of the former German settlements with their condition in the 19th early 20th centuries. They are trying to identify how the German-speaking population influenced the development of the region.

Students develop knowledge not only how to create a map but also enhance visual and descriptive skills. Technical equipment and computer applications are used as "tools" for the development of specialized knowledge (Brauckmann, 2020).

In the process of training students should: localize the object on the map; determine the spatial position and location (in particular, to localize a settlement that no longer exists); interpret knowledge about objects and phenomena; understand the qualitative and quantitative characteristics, condition, relationships, dynamics (for example, the relationship between the development of German industry and the availability of natural resources) (Tsemenkova, 2007).

The formation of many scientific concepts would be impossible without the introduction of systems of signs and methods for operating them. The appearance of the signs, their combinations and combinations contributes to the creative processes of thinking, facilitates penetration into complex and hidden connections. The advantage of conventional signs is that they not only accumulate a significant amount of information but also make it possible to trace spatio-temporal relationships and relationships, the knowledge of which by means of the language of words would be extremely difficult. In the learning 
process, students must develop their own way of forming concepts, scientific abstractions.

Statement of the basic material. Teaching materials are divided into three blocks.

The first block is the QGIS database and reference generalized maps (OpenStreetMap etc.). The second block is pre-created maps of the cultural development of the Germans in Zaporizhzhia oblast. The third block is tabular data with historical sources in Excel.

The first block of teaching materials is QGIS 3.18 software. Initially, it is supposed to teach students the basics of working in GIS. The main points that are emphasized: creating a simple project, choosing the right projection and coordinate system, choosing a base map. Particular attention is paid to working with pop-ups and adding links to historical sources

The second block: teaching historical maps of the German settlements of Prishibskaya volost. Students must learn to open these maps in a GIS and analyze the history of German settlements in time and space.

The position of Pryshibskaya volost is shown on the map of modern Ukraine. Now it is a part of Zaporizhia oblast, South Ukraine. The foundation of the German settlements began in 1804.27 colonies were established there in 19th century. The presented map shows the time of foundation of the colonies. Five stages are highlighted 1804-1816, 1816-1828, 1828-1840, 1840-1852 and 1852-1864. The majority of colonies were established at the initial stage of foundation period.

One of the maps presents religion situation in the settlement. Lutherans and Catholics took part in the settlement. The map contains information about the religion of the inhabitants as well as the location of religious buildings (church and houses of prayer).

The colonists gave the settlements German names, however, all settlements were renamed during the 20th century. After the deportation of the Germans, Russian names were given to the settlements and part of them was included in neighboring ones. Some settlements were deregistered because the residents left their homes forever.

In 1945 German settlements lost their initial names. In the 1950s, some settlements were excluded from the State register list (Hochheim, Blumenthal, Tiefenbrun, Waldorf Durlach and Hoffenthal). 
Next map shows us current names of the settlements and the existing of the ones. In addition to the settlements that disappeared in the 1950s, Durlach and Neu-Nassau do not exist now. The process of localization of the settlement and clarification of its current name is carried out using the overlay of three-verst map and OSM standart.

Water availability was decisive when setting up a settlement. Thus, we created the map, which shows base water supply for people. It shows the geographical features of the location of the colonies, water sources. The main water sources were the Kurkular, the Molochna and the Chungul rivers. The settlers also took water from wells and ravine (the lowering of the earth surface).

For each settlement, a specific plot of land was allocated. Area of the settlements was determined by the population. Information on the size of land ownership is presented on the map. We took four years 1858, 1884, 1906 and 1913. The largest settlement was Heidelberg, the smallest - Durlach.

We analyzed the number of yards in the settlements and next map shows the dynamics of the number of yards on marked dates: $1843,1864,1884,1896,1913,1925$. Eventually, it is clear from the map that an upward tendency prevailed during the second part of XIX begining of XX century. However, in 1884 the number of yards was decreased and jumped considerably only in 1925 .

Other maps characterize the population density of the colonies in 1884, 1906 and 1913. The average population density fluctuated between 0.09 and 0.193 people per desyatina (1.09 hectar). Between 1906 and 1913 the density slowed down.

There were a lot of plants and factories in the settlements. The map shows the industrial composition and location of enterprises at the end of the 19th - beginning of the 20th centuries. Three maps show workshops indicating their specialization. For a more complete coverage of their location, information is presented in a regional aspect.

Due to the fact that the main industry was flour milling, the distribution of mills is shown on a separate map. Mills were almost in every settlement. There was also an oil mill in Alexanderheim.

The geography of drinking establishments, indicating their type, is presented in the proposed slide. There were only three Taverns, three restaurants, four pubs two wine cellars in 27 settlements. 
The colonists were quite active in trade. In the settlements the most popular product was bread. The bread shops were almost everywhere in Prishibskaya volost. There were also manufactory stores, grocery stores, book shops, pharmacy.

The education was important in the life of the colonists. Different types of educational institutions were available in every settlement. Educational network is presented on the map. There was elementary and specialized school in each settlement, and school for deafhead in Prishib.

The third block are literature and sources related to the settlement of Germans in the area of the Molochna River. Initially, it is planned to transfer data from these historical sources to Word and Excel. Next is the translation of this information into QGIS attribute data and the creation of their own maps on the history of the German settlements.

The main stages of creating new maps by students are creating a project in QGIS and choosing a base map; creating an attribute tables relating to the following aspects of the history of the Germans in Zaporizhzhia oblast: features of agriculture (Andrievskiy, 1915); forestry (SAZR, f. F-250, vol. 1, № 165); features of livestock (Materialy podvornoy perepisi, 1915); landownership (Krylova, 2010); significant events, famous residents ("O pozhertvovaniyakh", 1854); creating a layout of new maps; analysis of the maps.

All data on the map should be confirmed by a link to an external resource (in word file). Time changes of individual indicators can be visualized with Time manager plugin. Additional information can be visualized through pop-up item.

The main problems that may arise in the process of working with historical sources when creating maps. Sources often have inconsistencies, are partially lost, incomprehensible and contradictory. The meaning of a certain piece of data cannot exist without interpretations that are subjective by definition. And all these aspects must be taken into account when introducing a source into an information system.

Additional problems arise when several sources are used in a historical study, primarily the coordination of these sources, the meaning of which depends on the spatial and temporal context. For example, land tenure censuses for different years often differ in accounting methods, so it is difficult to compare or combine them. 
The specificity of historical electronic cartography and historical geographic information systems is that their content should reflect not only a specific situation in the region being mapped, but also its development over a period of time. One of the tasks of historical cartography is to display the dynamics of objects fixed on the map: moving, changing boundaries, the emergence of new objects. In this case, it is important not only to put a list of events on the map, but also to show their sequence so that the card consumer can trace all significant changes from the initial conditions. It is the unresolved problems of spatiotemporal analysis that led to the insufficient demand for GIS technologies when working with the analysis of long historical processes. So, Jan Gregory believes that the map can represent only one of the components of the geographic information system for history - space (Gregory, 2003).

The other two components - time and topic - are broadcast in the form of textual information or a combination of several cards at different time intervals. The starting point for this statement is the fact that initially in the GIS it was not possible to analyze time and space at the same time (Grishin, 2017).

Conclusions. New socio-economic conditions for the development of Ukraine at the beginning of the XXI century require the formation of a powerful scientific, personnel potential of the country. The modern domestic economy can effectively develop if there are specialists who have consciously chosen a profession taking into account the real needs of society. The ongoing modernization of the education system is aimed at solving the problems of graduates entering the labor markets, and, consequently, at updating the system of pre-vocational and narrowly vocational education, which determines the state-wide need for realizing the life and professional self-determination of schoolchildren and students. That is why the priority is the concept of introducing GIS technologies into the training system for the development of new abilities and skills useful in the process of life and professional selfdetermination of pupils and students in changing living conditions.

The effective work of an educational institution in professional and personal orientation is built, on the one hand, taking into account the personal interests and abilities of the child, his rights to self-determination, and, on the other hand, socio-economic feasibility. For its implementation, new conditions must be created that meet the challenges 
of the time when the school or university environment acquires the properties of a multicultural educational environment and becomes the epicenter of a wide educational space in which students form not only narrowly-oriented but also personal qualities. Such personal qualities include a developed historical, ecological, as well as multicultural spatial worldview, aesthetic views and beliefs of a person based on the principles of tolerance, non-violence, which form a single picture of the world in consciousness and are the foundation of its productive activity.

Currently, one of the priority areas of the process of informatization of modern society is GIS using. It is significant that the use of GIS does not in itself implement the new educational paradigm of continuous learning, but is a powerful tool for putting it into practice. Of course, for the effective use of GIS in education, appropriate organization of the learning process, information and training resources, as well as the willingness and ability of teachers to work within the framework of the new educational paradigm are necessary. The pace of technological development, their cardinal change over the life of one generation, requires not only the development of new technological means, but also the understanding that this process will be constant.

Modern GIS provide access, both for the teacher and students, to the electronic sources of cartographic information for the possibilities of its processing, which makes it possible to grow creatively based on their use in the educational process. The use of GIS for educational purposes involves the individualization of training based on interactivity and optimization of training time. This direction is a strategic goal and is designated as the formation of a continuing education system. Achieving the prescribed goals is carried out through the introduction of GIS in the organization of the educational process, which ensures the effective implementation of new learning models.

The presence of computer equipment in a school or university in itself does not solve the issue of its effective use in the educational process. Most teachers do not have a sufficient level of information and communication competencies, course training and retraining programs for teachers are mainly not focused on the study and application of new information technologies in the educational process. Today, 
given the needs of the development of education, the content and technology of conducting classes for students from the point of view of practice are not well developed.

Despite the fact that GIS is currently widely used, research on the possibility and results of their use is practically absent, which suggests that there are contradictions between: the need for the formation of competence of spatial analysis and thinking among graduates of secondary and higher educational institutions and insufficient theoretical research this phenomenon in modern pedagogical science.

There is a problem of poorly developed methodological approaches to the use of modern information technologies in the existing education system of Ukraine.

There is also an objective need for the use of GIS in professional pedagogical activities for the formation of professional self-determination of students and advanced training of teachers.

Using visualized historical sources, teaching methods which use historical maps in GIS significantly improve the learning process of schoolchildren and students.

The use of historical GIS technologies contributes to the formation of students' skills: read the information of the historical maps; search for objects or information by given parameters, for example, by name; carry out calculations on digital maps; form the spatial thinking of students demonstrating the historical objects in three-dimension; create own digital maps especially the ones based on the results of student observations. In the future, we plan to undertake a more detailed study of foreign experience (methodology) of using the historical maps in GIS in the process of studying local history.

\section{Джерела та література}

Адресная книга заводов, мастерских и складов с/х машин и орудий: составлено по сведениям 1911-1912 г2. (1909 - некоторые). (1912). Санкт-Петербург.

Андриевский, Ф.Н. (1915). Статистический справочник Таврической губернии. Часть 2, вып. 3: Мелитопольский уезд. Список населенных мест. Симферополь.

Боряк, Г.В., \& Cосса, P.I. (2012). ГІС-Атлас Голодомору в Україні 1932-1933 рр. Наџіональне картографування: стан, проблеми та перспективи розвитку: збірник матеріалів V Всеукраїнської науково-практичної конференції «Національні атласи у форму- 
ванні глобального інформаційного простору» (м. Київ, 13-14 вересня 2012 р.). (Вип. 5, с. 30-35). Київ.

Винокурова, Н.Ф., Бадьин, М.М., \& Бадьина, О.Н. (2014). Изучение географического краеведения в школе средствами информационнокоммуникативных технологий. Весник Минского университета, 2. Взято с https://cyberleninka.ru/article/n/izuchenie-geograficheskogo-kra evedeniya-v-shkole-sredstvami-informatsionno-kommunikativnyh-tehno logiy.

ГАЗО - Государственный архив Запорожской области. Ф. Ф-250, оп. 1, д. 165. Сведения о лесокультурных работах и лесоводстве на участках частных землевладельцев. 1895-10.06.1899 г. 196 л.

Гришин, Е.С. (2017). Технологии и методика применения пространственно-временного анализа в специально исторических ГИСпроектах. Историческая информатика, 2, 74-84. doi: 10.7256/25857797.2017.2.23295. Взято с https://nbpublish.com/library_read_article. php?id=23295.

Дизендорф, В.Ф. (Сост.). (2006). Немиы России: населенные пункты и места поселения: энциклопедический словарь. Москва: «ЭРН».

Крилова, А.М. (2010). Земські статистичні публікації як джерело дослідження землеволодіння етнічних та соціальних груп Північного Приазов’я. Наукові прачі історичного факультету Запорізького національного університету, XXVIII, 446-451. Запоріжжя: ЗНУ.

Лебедев, П. (1915). Карта Мелитопольского уезда Таврической губернии: по сведениям 1889 года.

Материаль подворной переписи Мелитопольского уезда. Вып. 1: Таблицы сведений о крестьянском населении, скотоводстве, землевладении и землепользовании. (1915). Симферополь.

Населенные места Российской империи в 500 и более жителей с указанием всего наличного в них населения и числа жстелей преобладающих вероисповеданий, по данным Первой всеобщей переписи населения 1897 г. (1905). Санкт-Петербург.

O пожертвованиях сделанных в пользу войск колонистами и государственными крестьянами. (1854). ЖМГИ, 53 (11), 73-80.

Пинягин, С.В. (2010). Опыт германских ученых по созданию автоматизированной системы обработки данных исторических источников KLEIO. Вестник Челябинского государственного университета. История, 15 (196), вып. 40, 168-175.

Приложение ко всеподданнейтему отчету о состоянии Таврической губернии за 1889 год. (1890). Симферополь.

Рыгалова, М.В. (2014). Зарубежный опыт применения ГИС в исторических исследованиях: основные направления. Известия Алтай- 
ского государственного университета. История, 4/1, 199-203. doi: 10.14258/izvasu(2014)4.1-33. Взято с https://cyberleninka.ru/ article/n/zarubezhnyy-opyt-primeneniya-gis-v-istoricheskih-issledova niyah-osnovnye-napravleniya.

Рябко, А.В., \& Кухарчук, Р.П. (2014). Інформаційні технології в історії. Вісник Глухівського наиіонального педагогічного університету ім. Олександра Довженка. Сер. Педагогічні науки, 25, $141-146$.

Топографическая карта Генерального штаба Красной Армии. (1941).

Цеменкова, С.И. (2007). Картографирование исторических данных: методологические проблемы использования ГИС. Документ. Архив. История. Современность, 7, 262-269. Екатеринбург: Изд-во Урал. ун-та.

Altaweel, M. (2016). How GIS is used to understand history. Gis Lounge. Retrieved from https://www.gislounge.com/gis-used-understand-history/.

Brandes, D., \& Dönninghaus, V. (Hrsg.). (1999). Bibliographie zur Geschichte und Kultur der Rußlanddeutschen. Bd. 2: Von 1917 bis 1998. München.

Brauckmann, S. (2012). GIS in Primary Schools - Teaching Local History and Cultural Landscape. In T. Jekel, A. Car, J. Strobl, \& G. Griesebner (Eds.), GIS_Forum 2012: Geovizualisation, Society and Learning (pp. 309-317). Berlin: Offenbach.

Diamond, E., \& Bodenhamer, D.J. (2001). Race and the Decline of Mainline Protestantism in American Cities: a GIS Analysis of Indianapolis in the 1950s. History and Computing, 13 (1).

Gregory, I.N. (2003). A Place in History. A Guide to Using GIS in Historical Research. Retrieved from http://hds.essex.ac.uk/g2gp/gis/index.asp.

Hammond, T. (2007). Transforming the history curriculum with geospatial tools. Contemporary Issues in Technology and Teacher Education, 14 (3), 266-287.

Lambrinos, N., \& Asiklari, F. (2014). The introduction of GIS and GPS through local history teaching in primary school. European Journal of Geography, 5 (1), 32-47. Retrieved from https://www.researchgate.net/ publication/261622478_The_introduction_of_GIS_and_GPS_through_loc al_history_teaching_in_primary_school.

Milson, A.J., \& Alibrandi, M. (2008). Digital Geography: Geospatial Technologies in the Social Studies Classroom, Information Age. Retrieved from https://www.tandfonline.com/doi/abs/10.1080/00221341.2011.521849.

Richardson, D. (2020). Teaching History with GIS. Retrieved from https://www.esri.com/about/newsroom/arcnews/teaching-history-with-gis/. 


\section{References}

Adresnaya kniga zavodov, masterskikh $i$ skladov s/h mashin $i$ orudiy: sostavleno po svedeniyam 1911-1912 gg. (1909 - nekotorye) [Address book of factories, workshops and warehouses of agricultural machines and implements: Compiled according to information from 1911-1912]. (1912). Saint Petersburg [in Russian].

Andrievskiy, F.N. (1915). Statisticheskiy spravochnik Tavricheskoy gubernii. Ch. 2, vyp. 3: Melitopolskiy uezd. Spisok naselennykh mest [Statistical reference book of the Tauride province. Pt. 2, iss. 3: Melitopol district. List of settlements]. Simferopol [in Russian].

Boriak, H.V., \& Sossa, R.I. (2012). HIS-Atlas Holodomoru v Ukraini 1932-1933 rr. [Geographic Information System (GIS)-based Digital Atlas of the Holodomor in Ukraine 1932-1933]. Natsionalne kartohrafuvannia: stan, problemy ta perspektyvy rozvytku: zbirnyk materialiv V Vseukrainskoi naukovo-praktychnoi konferentsii «Natsionalni atlasy $\mathrm{u}$ formuvanni hlobalnoho informatsiinoho prostoru» (m. Kyiv, 13-14 veresnia 2012 r.) - National mapping: state, problems and prospects of development: collection of materials of the $\mathrm{V}$ AllUkrainian scientific-practical conference "National atlases in the formation of the global information space" (Kyiv, September 13-14, 2012). (Vol. 5, pp. 30-35). Kyiv [in Ukrainian].

Vinokurova, N.F., Badin, M.M., \& Badina, O.N. (2014). Izuchenie geograficheskogo kraevedeniya v shkole sredstvami informatsionnokommunikativnykh tekhnologiy [Geographical study of local history in the school by means of information and communication technologies]. Vesnik Minskogo universiteta - Bulletin of Minsk University, 2. Retrieved from https://cyberleninka.ru/article/n/izuchenie-geograf icheskogo-kraevedeniya-v-shkole-sredstvami-informatsionno-kommu nikativnyh-tehnologiy [in Russian].

SAZR - Gosudarstvennyy arkhiv Zaporozhskoy oblasti. F. F-250, op. 1, d. 165. Svedeniya o lesokulturnykh rabotakh i lesovodstve na uchastkakh chastnykh zemlevladeltsev. 1895-10.06.1899 g. [State Archives of Zaporizhzhya Region. F. F-250, vol. 1, № 165. Information about forestry and forestry activities on private landowner plots. 1895-10.06.1899] [in Russian].

Grishin, E.S. (2017). Tekhnologii i metodika primeneniya prostranstvennovremennogo analiza v spetsialno istoricheskikh GIS-proektakh [Technologies and methods of using space-time analysis in specially historical GIS projects]. Istoricheskaya informatika - Historical informatics, 2, 74-84. doi: 10.7256/2585-7797.2017.2.23295. Retrieved from https://nbpublish.com/library_read_article.php?id=23295 [in Russian]. 
Dizendorf, V. (Comp.). (2006). Nemtsy Rossii: naselennye punkty i mesta poseleniya: entsiklopedicheskiy slovar [Die Deutschen Russlands: Siedlungen und Siedlungsgebiete: Lexikon]. Moskva. Retrieved from http://kraeved.od.ua/history/deutsche.php [in Russian].

Krylova, A. (2010). Zemski statystychni publikatsii yak dzherelo doslidzhennia zemlevolodinnia etnichnykh ta sotsialnykh hrup Pivnichnoho Pryazovia [The descriptive-statistical publications of Zemstva as a source of ethnic and social population groups landownership in North Priasovie region]. Naukovi pratsi istorychnoho fakultetu Zaporizkoho natsionalnoho universytetu - Scientific works of Historical department of Zaporizhzhia National University, 28, 446-451. Zaporizhzhia. Retrieved from http://www.istznu.org/page/issues/28/krylova.pdf [in Ukrainian].

Lebedev, P. (1889). Karta Melitopolskogo uezda Tavricheskoy gubernii: po svedenyam 1889 goda [Map of Melitopol uyezd of the Tauride province: according to 1889] [in Russian].

Materialy podvornoy perepisi Melitopolskogo uezda. Vyp. 1: Tablitsy svedeniy o krestyanskom naselenii, skotovodstve, zemlevladenii $i$ zemlepolzovanii [Materials of the court census of Melitopol district. Issue. 1: Tables of information on the peasant population, cattle breeding, land tenure and land use]. (1915). Simferopol [in Russian].

Naselennye mesta Rossiyskoy imperii v 500 i bolee zhiteley s ukazaniem vsego nalichnogo $v$ nikh naseleniya $i$ chisla zhiteley preobladayushchikh veroispovedaniy, po dannym Pervoy vseobshchey perepisi naseleniya $1897 \mathrm{~g}$. [Populated places of the Russian Empire of 500 or more inhabitants, indicating the total population in them and the number of inhabitants of the predominant religions, according to the First General Census of 1897]. (1905). Saint Petersburg [in Russian].

O pozhertvovaniyakh sdelannykh $\mathrm{v}$ polzu voysk kolonistami i gosudarstvennymi krestyanami [About donations made in favor of troops by colonists and state peasants]. (1854). Zhurnal Ministerstva gosudarstvennykh imushchestv - Journal of the Ministry of State, 53 (11), 73-80 [in Russian].

Pinyagin, S.V. (2010). Opyt germanskikh uchenykh po sozdaniyu avtomatizirovannoy sistemy obrabotki dannykh istoricheskikh istochnikov KLEIO [The experience of German scientists in the creation of an automated data processing system for historical sources KLEIO]. Vestnik Chelyabinskogo gosudarstvennogo universiteta. Istoriya Bulletin of Chelyabinsk State University. History, 15 (196), iss. 40, 168-175 [in Russian]. 
Prilozhenie ko vsepoddanneyshemu otchetu o sostoyanii Tavricheskoy gubernii za 1889 god [Supplement to the all-subject report on the state of the Taurida province for 1889]. (1890). Simferopol [in Russian].

Rygalova, M.V. (2014). Zarubezhnyy opyt primeneniya GIS v istoricheskikh issledovaniyakh: osnovnye napravleniya [Foreign experience in the use of GIS in historical research: main directions]. Izvestiya Altayskogo gosudarstvennogo universiteta. Istoriya - Bulletin of the Altai State University. History, 4/1, 199-203. doi: 10.14258/izvasu(2014) 4.1-33. Retrieved from https://cyberleninka.ru/article/n/zarubezhnyyopyt-primeneniya-gis-v-istoricheskih-issledovaniyah-osnovnye-naprav leniya [in Russian].

Riabko, A.V., \& Kukharchuk, R.P. (2014). Informatsiini tekhnolohii v istorii [Information technology in history]. Visnyk Hlukhivskoho natsionalnoho pedahohichnoho universytetu im. Oleksandra Dovzhenka. Seriia: Pedahohichni nauky - Bulletin of the Glukhiv Alexander Dovzhenko National Pedagogical University. Series: Pedagogical sciences, 25, 141-146 [in Ukrainian].

Topograficheskaya karta Generalnogo shtaba Krasnoy Armii [Topographic map of the General Staff of the Red Army]. (1941). [in Russian].

Tsemenkova, S.I. (2007). Kartografirovanie istoricheskikh dannykh: metodologicheskie problemy ispolzovaniya GIS [Historical data mapping: methodological problems of using GIS]. Dokument. Arkhiv. Istoriia. Sovremennost, 7, 262-269. Ekaterinburg: Izd-vo Ural. un-ta. Retrieved from http://elar.urfu.ru/handle/10995/20490?locale=en [in Russian].

Altaweel, M. (2016). How GIS is used to understand history. Gis Lounge. Retrieved from https://www.gislounge.com/gis-used-understand-history/.

Brandes, D., \& Dönninghaus, V. (Hrsg.). (1999). Bibliographie zur Geschichte und Kultur der Rußlanddeutschen. Bd. 2: Von 1917 bis 1998. München.

Brauckmann, S. (2012). GIS in Primary Schools - Teaching Local History and Cultural Landscape. In T. Jekel, A. Car, J. Strobl, \& G. Griesebner (Eds.), GIS_Forum 2012: Geovizualisation, Society and Learning (pp. 309-317). Berlin: Offenbach.

Diamond, E., \& Bodenhamer, D.J. (2001). Race and the Decline of Mainline Protestantism in American Cities: a GIS Analysis of Indianapolis in the 1950s. History and Computing, 13 (1).

Gregory, I.N. (2003). A Place in History. A Guide to Using GIS in Historical Research. Retrieved from http://hds.essex.ac.uk/g2gp/gis/index.asp.

Hammond, T. (2007). Transforming the history curriculum with geospatial tools. Contemporary Issues in Technology and Teacher Education, 14 (3), 266-287. 
Lambrinos, N., \& Asiklari, F. (2014). The introduction of GIS and GPS through local history teaching in primary school. European Journal of Geography, 5 (1), 32-47. Retrieved from https://www.researchgate.net/ publication/261622478_The_introduction_of_GIS_and_GPS_through_loc al_history_teaching_in_primary_school.

Milson, A.J., \& Alibrandi, M. (2008). Digital Geography: Geospatial Technologies in the Social Studies Classroom, Information Age. Retrieved from https://www.tandfonline.com/doi/abs/10.1080/00221341.2011.521849.

Richardson, D. (2020). Teaching History with GIS. Retrieved from https://www.esri.com/about/newsroom/arcnews/teaching-history-with-gis/.

Стаття надійшла до редакиії 12.10.2020 p. 